University of Nebraska - Lincoln

DigitalCommons@University of Nebraska - Lincoln

1967

\title{
Sympatry Changes and Hybridization Incidence in Mallards and Black Ducks
}

Paul A. Johnsgard

University of Nebraska-Lincoln, pajohnsgard@gmail.com

Follow this and additional works at: https://digitalcommons.unl.edu/biosciornithology

Part of the Ornithology Commons

Johnsgard, Paul A., "Sympatry Changes and Hybridization Incidence in Mallards and Black Ducks" (1967). Papers in Ornithology. 76.

https://digitalcommons.unl.edu/biosciornithology/76

This Article is brought to you for free and open access by the Papers in the Biological Sciences at DigitalCommons@University of Nebraska - Lincoln. It has been accepted for inclusion in Papers in Ornithology by an authorized administrator of DigitalCommons@University of Nebraska - Lincoln. 


\title{
Sympatry Changes and Hybridization Incidence in Mallards and Black Ducks ${ }^{1}$
}

\author{
PAUL A. JOHNSGARD \\ Department of Zoology and Physiology, University of Nebraska, Lincoln 68508 \\ Astract: Changes in general fall and winter distributions of \\ Mallards and Black Ducks over the past century have resulted in \\ markedly increased sympatric contact during pair formation between \\ these two forms, and have been responsible for increased opportunities \\ for hybridization. Bureau of Sport Fisheries and Wildlife records of \\ hybrids from 34 states indicate a minimal current hybridization rate that \\ is about $4 \%$ of the frequency expected on the basis of mating according \\ to mathematical probabilities of chance contact. Thus, hybridization \\ is most frequent where both forms are almost equally abundant, \\ indicating that no reinforcement of differences reducing hybridization \\ in the primary zone of contact is detectable. The primary zone of \\ sympatry has moved eastward approximately 300 miles during the past \\ half century and will almost certainly continue to do so. Owing to its \\ much smaller gene pool, the Black Duck is vulnerable to eventual \\ swamping through hybridization and introgression, although the present \\ hybridization rate is sufficiently low as to make this unlikely in the \\ foreseeable future.
}

Although numerous examples of secondary contact and ensuing hybridization in birds have now been well documented and studied to varying degrees (Sibley, 1961), a major difficulty with nearly all such studies has been an absence or paucity of quantitative information on changes in the degree of secondary contact during historical times and related changes in hybridization incidence. Furthermore, in most species it is impossible or impractical to collect a large enough series of specimens in such zones of sympatry to allow a statistical evaluation of hybrid incidence over various portions of these zones. However, the abundance, conspicuous nature, and extensive banding and harvest analyses of waterfowl by state and federal agencies provide at least partial exceptions to these limitations, and as a result the family Anatidae might be expected to provide useful data in this regard.

Among the North American species of waterfowl, only the Mallard-like ducks (Anas platyrhynchos and related forms) exhibit hybridization of a significant degree under wild conditions (Johnsgard, 1961a). Two major zones of sympatry and hybridization occur among these forms at present. These include the limited zone of contact in New Mexico between the sexually dimorphic Mallard ( $A . p$. platyrhynchos) and the sexually monomorphic Mexican Duck (Anas diazi), and the much more extensive zone of contact in the eastern states between the Mallard and another sexually monomorphic form, the Black Duck (Anas rubripes). No detailed information is avail-

${ }^{1}$ Studies (No. 378) from the Department of Zoology and Physiology, University of Nebraska. 
able regarding the situation in New Mexico, but determinations of the degree of sympatry and estimates of hybridization incidence for Mallards and Black Ducks have been made previously (Johnsgard, $1961 \mathrm{a}, 1961 \mathrm{~b})$. In these studies it was concluded that the Black Duck is not fully specifically distinct from the Mallard but that the present hybridization incidence is sufficiently low that it probably does not yet endanger seriously the much smaller gene pool of the Black Duck.

Furthermore, it was concluded that the degree of contact between Mallards and Black Ducks is increasing, probably primarily because habitat changes in the eastern states are allowing the grassland-adapted Mallard to colonize large areas formerly occupied largely or entirely by the forest-adapted Black Duck. The extent of these changes in general distributions has been documented (Johnsgard, 1961b) through the use of the Audubon Society Christmas Counts, which have been conducted annually since 1900. State-wide Mallard: Black Duck ratios for the first 40 years, from 1900 to 1939, were first calculated by Wing (1943), and provide an estimate of relative state wintering-ground distributions for this period. Because pair-formation in Mallards and Black Ducks occurs during the late fall and winter periods (Johnsgard, 1960), such winter figures may be regarded as an estimate of effective sympatry between the two forms. Johnsgard (1961b) compared Wing's data (recalculated from ratios to percentages) with corresponding data for the following period from 1940 to 1960 ; marked changes from the situation as described by Wing were indicated.

There would be little reason for another analysis so soon after my earlier one were it not for the fact that quantitative data on hybridization incidence in these states have now become available through the Bureau of Sport Fisheries and Wildlife's Duck Wing Collection Survey of waterfowl hunter kills. This survey is based on duck wings contributed by cooperating hunters. From these wings (and especially from the secondaries and their coverts) it is possible not only to distinguish readily Mallards from Black Ducks but also to recognize at least a significant proportion of the hybrids. The resulting data, which are based on this single source, are thus clearly minimal figures, and undoubtedly many specimens exhibiting minor hybrid traits or those which exhibit parental recombination phenotypes go unrecognized. In spite of these limitations, the relatively great wealth of data provided by these wing collections offer the first feasible means of an analysis of minimal hybrid incidence, because earlier sources of evidence regarding hybrid frequency were of unequal quality and available for only a few states (Johnsgard, 1961a). For these reasons the present analysis is presented, in hopes of stimulating additional studies on hybrid incidence in these and other species.

Table 1 presents an updated version of the information presented earlier (Wing, 1943; Johnsgard, 1961b), summarizing Audubon Christmas Count information on Mallards and Black Ducks in the 
TABLE 1.- Relative numbers of Mallards, Black Ducks and hybrids, 1900-1939 and early 1960's, eastern North America

\begin{tabular}{|c|c|c|c|c|}
\hline \multirow{3}{*}{$\begin{array}{l}\text { State or Province } \\
\text { New Brunswick } \\
1960-1964 \text { (Xmas Counts) }\end{array}$} & \multicolumn{2}{|c|}{$\begin{array}{c}\text { Total } \\
\text { Black Ducks } \\
(\%)\end{array}$} & \multirow[t]{2}{*}{$\begin{array}{l}\text { Total } \\
\text { Mallards } \\
(\%)\end{array}$} & \multirow[t]{2}{*}{$\begin{array}{c}\text { Total } \\
\text { Hybrids }^{1} \\
(\%) \\
\end{array}$} \\
\hline & \multirow{2}{*}{\multicolumn{2}{|c|}{$909(100.00)$}} & & \\
\hline & & & $0 \quad(0.00)$ & \\
\hline Nova Scotia & & & & \\
\hline 1960-1964 (Xmas Counts) & 2,805 & $(99.93)$ & $2(0.07)$ & \\
\hline \multicolumn{5}{|l|}{ Quebec } \\
\hline 1960-1964 (Xmas Counts) & 4,298 & $(94.54)$ & $248 \quad(5.46)$ & \\
\hline \multicolumn{5}{|l|}{ Maine } \\
\hline 1960-1964 (Xmas Counts) & 1,773 & $(99.50)$ & $(0.5)$ & \\
\hline 1960-1964 (Wing Counts) & 3,569 & $(95.79)$ & $157 \quad(4.21)$ & $25(0.67)$ \\
\hline \multicolumn{5}{|l|}{ New Hampshire } \\
\hline 1960-1964 (Xmas Counts) & 2,934 & $(71.16)$ & $1,189(28.39)$ & \\
\hline 1960-1964 (Wing Counts) & 895 & $(93.03)$ & $67 \quad(6.97)$ & $11(1.14)$ \\
\hline \multicolumn{5}{|l|}{ Vermont } \\
\hline 1960-1964 (Xmas Counts) & 697 & $(67.73)$ & $332(32.27)$ & \\
\hline 1960-1964 (Wing Counts) & 1,259 & $(79.33)$ & $328(20.67)$ & $31(1.95)$ \\
\hline \multicolumn{5}{|l|}{ Massachusetts } \\
\hline $1900-1939$ & & $(99.28)$ & $(0.72)$ & \\
\hline 1960-1964 (Xmas Counts) & 81,303 & $(90.62)$ & $8,412 \quad(9.38)$ & \\
\hline 1960-1964 (Wing Counts) & 2,985 & $(87.18)$ & $439(12.82)$ & $59^{\prime}(1.72)$ \\
\hline \multicolumn{5}{|l|}{ Rhode Island } \\
\hline $1900-1939$ & & $(99.35)$ & $(0.65)$ & \\
\hline 1960-1964 (Xmas Counts) & 15,245 & $(95.83)$ & $664 \quad(4.17)$ & \\
\hline 1960-1964 (Wing Counts) & 1,044 & (89.69) & $120(10.31)$ & $15(1.29)$ \\
\hline \multicolumn{5}{|l|}{ Connecticut } \\
\hline 1900-1939 & & $(94.31)$ & $(5.69)$ & \\
\hline 1960-1964 (Xmas Counts) & 32,424 & $(61.12)$ & $20,625(38.88)$ & \\
\hline 1960-1964 (Wing Counts) & 1,075 & $(68.34)$ & $488(31.66)$ & $30(1.91)$ \\
\hline \multicolumn{5}{|l|}{ New York } \\
\hline $1900-1939$ & & $(96.12)$ & $(3.88)$ & \\
\hline 1960-1964 (Xmas Counts) & 135,149 & $(78.35)$ & $37,342(21.65)$ & \\
\hline 1960-1964 (Wing Counts) & 2,719 & $(52.80)$ & $2,431(47.30)$ & $94(1.83)$ \\
\hline \multicolumn{5}{|l|}{ New Jersey } \\
\hline $1900-1939$ & & $(99.17)$ & $(0.03)$ & \\
\hline 1960-1964 (Xmas Counts) & 107,646 & $(84.02)$ & $20,477(15.98)$ & \\
\hline 1960-1964 (Wing Counts) & 5,497 & (79.09) & $1,453(20.91)$ & $121(1.74)$ \\
\hline \multicolumn{5}{|l|}{ Pennsylvania } \\
\hline $1900-1939$ & & $(95.39)$ & $(4.61)$ & \\
\hline 1960-1964 (Xmas Counts) & 32,194 & $(39.56)$ & $49,193(60.44)$ & \\
\hline 1960-1964 (Wing Counts) & 990 & $(30.46)$ & $2,260(69.54)$ & $137(4.21)$ \\
\hline \multicolumn{5}{|l|}{ Delaware } \\
\hline 1900-1939 & & $(99.08)$ & $\ldots \ldots \ldots \ldots . .(0.92)$ & \\
\hline 1960-1964 (Xmas Counts) & 59,180 & $(50.46)$ & $58,103(49.54)$ & \\
\hline 1960-1964 (Wing Counts) & 1,199 & $(68.32)$ & $556(31.68)$ & $23(1.31)$ \\
\hline \multicolumn{5}{|l|}{ Maryland } \\
\hline $1900-1939$ & & $(94.08)$ & $(5.92)$ & \\
\hline 1960-1964 (Xmas Counts) & 55,428 & $(55.12)$ & $45,129(44.88)$ & \\
\hline 1960-1964 (Wing Counts) & 1,973 & $(62.79)$ & $1,169(37.21)$ & $66^{\prime}(2.10)$ \\
\hline
\end{tabular}

$1960-1964$ (Wing Counts) $1,973(62.79) \quad 1,169(37.21) \quad 66(2.10)$ centages. 
TABLE $1 .-$ (continued)

\begin{tabular}{|c|c|c|c|c|}
\hline State or Province & \multicolumn{2}{|c|}{$\begin{array}{c}\text { Total } \\
\text { Black Ducks } \\
(\%)\end{array}$} & \multirow[t]{2}{*}{$\begin{array}{c}\text { Total } \\
\text { Mallards } \\
(\%)\end{array}$} & \multirow[t]{2}{*}{$\begin{array}{c}\text { Total } \\
\text { Hybrids } \\
(\%)\end{array}$} \\
\hline \multirow{2}{*}{\multicolumn{5}{|c|}{$\begin{array}{c}\text { Virginia } \\
1900-1\end{array}$}} \\
\hline & & & & \\
\hline 1960-1964 (Xmas Counts) & 162 & $(72.41)$ & $24,446(27$ & \\
\hline 1960-1964 (Wing & 174 & $(55.17)$ & $954(44.83)$ & $33(1.55)$ \\
\hline \multicolumn{5}{|l|}{ North Carolina } \\
\hline $1900-1939$ & & $(90.13)$ & $(9.87)$ & \\
\hline 1960-1964 (Xmas Counts) & 37,756 & $(56.88)$ & $28,626(43.12)$ & \\
\hline $1960-1964(\mathrm{~W}$ & 670 & $(54.87)$ & $551^{\prime}(45.13)$ & $19(1.56)$ \\
\hline \multicolumn{5}{|l|}{ South Carolina } \\
\hline 1900-1939 & & $(71.35)$ & $\ldots .(28.65)$ & \\
\hline 4 (Xmas Counts) & 1,526 & $(12.71)$ & $10,482(87.29)$ & \\
\hline $1960-1$ & 06 & $(40.24)$ & $603(59.76)$ & $9(0.89)$ \\
\hline \multicolumn{5}{|l|}{ Georgia } \\
\hline $1900-1$ & & $(70.58)$ & $\ldots(29$ & \\
\hline 4 (Xmas Counts) & 990 & $(31.61)$ & $2,142(($ & \\
\hline $1960-19$ & 41 & $(21.69)$ & $148(78.31)$ & $3(1.59)$ \\
\hline \multicolumn{5}{|l|}{ Florida } \\
\hline $1900-$ & & $(65$ & $\ldots(3$ & \\
\hline $1960-$ & 717 & & 3,285 & \\
\hline $1960-1$ & 173 & $(45.89)$ & $204(54$ & $7(1.86)$ \\
\hline \multicolumn{5}{|l|}{ Ohio } \\
\hline \multicolumn{5}{|l|}{$1900-1939$} \\
\hline $1960-1964$ &, 029 & & 64,558 & \\
\hline $1960-1964(\mathrm{~W}$ & 823 & $(31$ & 4) & $52(2.02)$ \\
\hline \multicolumn{5}{|l|}{ West Virginia } \\
\hline 1900-1939 & & $(88.01)$ & $(11.99)$ & \\
\hline 19 & 3,606 & $(72$ & $1,348(27$ & \\
\hline $1960-19$ & 288 & $(59$ & $198(40$ & $12(2.47)$ \\
\hline \multicolumn{5}{|l|}{ Kentucky } \\
\hline $1900-193$ & & $(15.31)$ & (8....... $(84.69)$ & \\
\hline Counts) & 20,318 & & $85,464(80$ & \\
\hline $1960-1964$ & 566 & $(23.06)$ & 388 & $19^{\prime}(0.77)$ \\
\hline \multicolumn{5}{|l|}{ Tennessee } \\
\hline $1900-1939$ & & $(19.54)$ & $\ldots \ldots \ldots$ & \\
\hline 1960-1964 (Xm & 14,117 & $(3.34)$ & $62(96.66)$ & \\
\hline 1960-1964 (Wir & 780 & $(19.75)$ & $.25)$ & $2(0.55)$ \\
\hline \multicolumn{5}{|l|}{ Alabama } \\
\hline $1960-1$ & 52 & $(6$ & ) & \\
\hline $1960-1964($ & 320 & & 60 & 5( \\
\hline \multicolumn{5}{|l|}{ Mississippi } \\
\hline & & $(14.56)$ &.$(85.44)$ & \\
\hline 196 & 38 & $(10.67)$ & $210<0$ & \\
\hline $1960-$ & 4 & $(A)$ & 4 & $4(0.2$ \\
\hline \multicolumn{5}{|l|}{ Michigan } \\
\hline & & $(71.75)$ & $(28.2$ & \\
\hline 1960 & 4,005 & $(49.66)$ & $4,059(50.34)$ & \\
\hline 1960-1964 (Wi & 1,484 & $(30.94)$ & $3,313(69.06)$ & $58(1.21)$ \\
\hline \multicolumn{5}{|l|}{ Indiana } \\
\hline $1900-1939$ & & $(21.37)$ & 3) & \\
\hline $4(\mathrm{Xmas} C$ & 2,965 & $(15.40)$ & $16,291(84.60)$ & \\
\hline 1960-1964 (Wing Counts) & 597 & $(26.66)$ & $1,642(73.34)$ & $22(0.98)$ \\
\hline
\end{tabular}




\begin{tabular}{|c|c|c|c|c|}
\hline State or Province & \multicolumn{2}{|c|}{$\begin{array}{c}\text { Total } \\
\text { Black Ducks } \\
(\%)\end{array}$} & \multirow[t]{2}{*}{$\begin{array}{c}\text { Total } \\
\text { Mallards } \\
(\%)\end{array}$} & \multirow[t]{2}{*}{$\begin{array}{c}\text { Total } \\
\text { Hybrids } \\
(\%) \\
\end{array}$} \\
\hline Illinois & & & & \\
\hline 1900-1939 & & $(8.52)$ & $\ldots(91.48)$ & \\
\hline 1960-1964 (Xmas Counts) & 8,486 & $(4.70)$ & $171,986(95.30)$ & \\
\hline 1960-1964 (Wing Counts) & 310 & $(5.18)$ & $5,672(94.82)$ & $20(0.33)$ \\
\hline \multicolumn{5}{|l|}{ Wisconsin } \\
\hline $1900-1939$ & & $(10.10)$ & $\ldots(89.90)$ & \\
\hline 1960-1964 (Xmas Counts) & 7,547 & $(16.32)$ & $38,688(83.68)$ & \\
\hline 1960-1964 (Wing Counts) & 1,282 & $(14.85)$ & $7,351(85.15)$ & $51(0.59)$ \\
\hline \multicolumn{5}{|l|}{ Minnesota } \\
\hline $1900-1939$ & & $(0.07)$ & $\ldots(99.93)$ & \\
\hline 1960-1964 (Xmas Counts) & 71 & $(2.45)$ & $4,825(97.55)$ & \\
\hline 1960-1964 (Wing Counts) & 176 & $(2.25)$ & $7,649(97.75)$ & $16(0.20)$ \\
\hline \multicolumn{5}{|l|}{ Iowa } \\
\hline $1900-1939$ & & $(0.22)$ & $\ldots(99.78)$ & \\
\hline 1960-1964 (Xmas Counts) & 160 & $(0.65)$ & $24,380(99.35)$ & \\
\hline $1960-1964$ (Wing Counts) & 52 & $(1.62)$ & $3,167(98.38)$ & $4(0.12)$ \\
\hline \multicolumn{5}{|l|}{ Missouri } \\
\hline $1900-1939$ & & $(0.70)$ & $(99.30)$ & \\
\hline 1960-1964 (Xmas Counts) & 3,132 & $(0.78)$ & $399,473(99.22)$ & \\
\hline 1960-1964 (Wing Counts) & 42 & $(1.05)$ & $3,975(98.95)$ & $3(0.07)$ \\
\hline \multicolumn{5}{|l|}{ Arkansas } \\
\hline $1900-1939$ & & $(0.33)$ & $\ldots(99.67)$ & \\
\hline 1960-1964 (Xmas Counts) & 14 & $(0.01)$ & $133,541(99.99)$ & \\
\hline $1960-1964$ (Wing Counts) & 59 & $(0.79)$ & $7,392(99.21)$ & $6(0.08)$ \\
\hline \multicolumn{5}{|l|}{ Louisiana } \\
\hline $1900-1939$ & & $(7.57)$ & $(92.43)$ & \\
\hline 1960-1964 (Xmas Counts) & 43 & $(1.85)$ & $2,283(98.15)$ & \\
\hline 1960-1964 (Wing Counts) & 77 & $(1.85)$ & $4,076(98.15)$ & $7(0.17)$ \\
\hline \multicolumn{5}{|l|}{ North Dakota } \\
\hline $1960-1964^{\prime}$ (Xmas Counts) & 0 & $(0.00)$ & $72(100.00)$ & \\
\hline 1961-1964 (Wing Counts) & 8 & $(0.15)$ & $5,159 \quad(99.85)$ & $4(0.08)$ \\
\hline \multicolumn{5}{|l|}{ South Dakota } \\
\hline $1900-1939$ & ... & $(0.21)$ & $\ldots \quad(99.79)$ & \\
\hline 1960-1964 (Xmas Counts) & 0 & $(0.00)$ & $44,447(100.00)$ & \\
\hline 1961-1964 (Wing Counts) & 3 & $(0.07)$ & $4,216(99.93)$ & $1(0.02)$ \\
\hline \multicolumn{5}{|l|}{ Nebraska } \\
\hline $1900-1939$ & $\ldots$ & $(0.00)$ & $\ldots(100.00)$ & 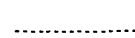 \\
\hline $1960-1964$ (Xmas Counts) & 1 & $(0.00)$ & $242,927(100.00)$ & \\
\hline 1961-1964 (Wing Counts) & 1 & $(0.03)$ & $3,494 \quad(99.98)$ & $0(0.00)$ \\
\hline \multicolumn{5}{|l|}{ Kansas } \\
\hline 1960-1964 (Xmas Counts) & 3 & $(0.00)$ & $258,598(100.00)$ & \\
\hline 1961-1964 (Wing Counts) & 1 & $(0.06)$ & $1,722(99.94)$ & $0(0.00)$ \\
\hline \multicolumn{5}{|l|}{ Oklahoma } \\
\hline 1960-1964 (Xmas Counts) & 13 & $(0.01)$ & $149,408 \quad(99.99)$ & \\
\hline $1961-1964$ (Wing Counts) & 3 & $(0.28)$ & $1,061 \quad(99.78)$ & $0(0.00)$ \\
\hline \multicolumn{5}{|l|}{ Texas } \\
\hline $1900=1939$ & & $(0.85)$ & $(99.15)$ & ....... \\
\hline 1960-1964 (Xmas Counts) & 77 & $(0.04)$ & $204,871 \quad(99.96)$ & $\ldots \ldots . . .1$ \\
\hline 1961-1964 (Wing Counts) & 22 & $(0.99)$ & $2,192 \quad(99.01)$ & $4(0.18)$ \\
\hline
\end{tabular}


eastern states and provinces for the period 1900-1939 (Wing's data) and also for the past five years, 1960-1964. Data for the intervening period, 1940-1959, are not included but are available (Johnsgard, 1961b). Although the calculated frequencies indicated for each area during the period 1900-1939 do not include actual sample sizes, it is probable that in most cases the total sample is smaller than for the later period, owing to a continually growing number of participants in these yearly counts. A few recognizable Mallard x Black Duck hybrids have sometimes been mentioned in these counts, but field identification of hybrids is not a reliable index to their abundance, because many recombinant individuals closely approaching parental conditions occur in $F_{2}$ and backcross generations (Phillips, 1915, 1921), thus diminishing the apparent frequency of hybrids. Table 1 also includes the Duck Wing Collection Survey totals of Mallards, Black Ducks and their hybrids recorded during the 1960-1964 period for each of the states in the areas of major or minor sympatry. Despite some exceptions, there is a general agreement of data from these two sources for the period in question. Where major differences do appear (as in New Hampshire, New York, New Jersey and Delaware), the Audubon count data would appear to be the more reliable estimate, owing to the generally larger sample sizes from that source.

To synthesize these figures into a single meaningful diagram is difficult at best, and no single method seems altogether suitable. How-

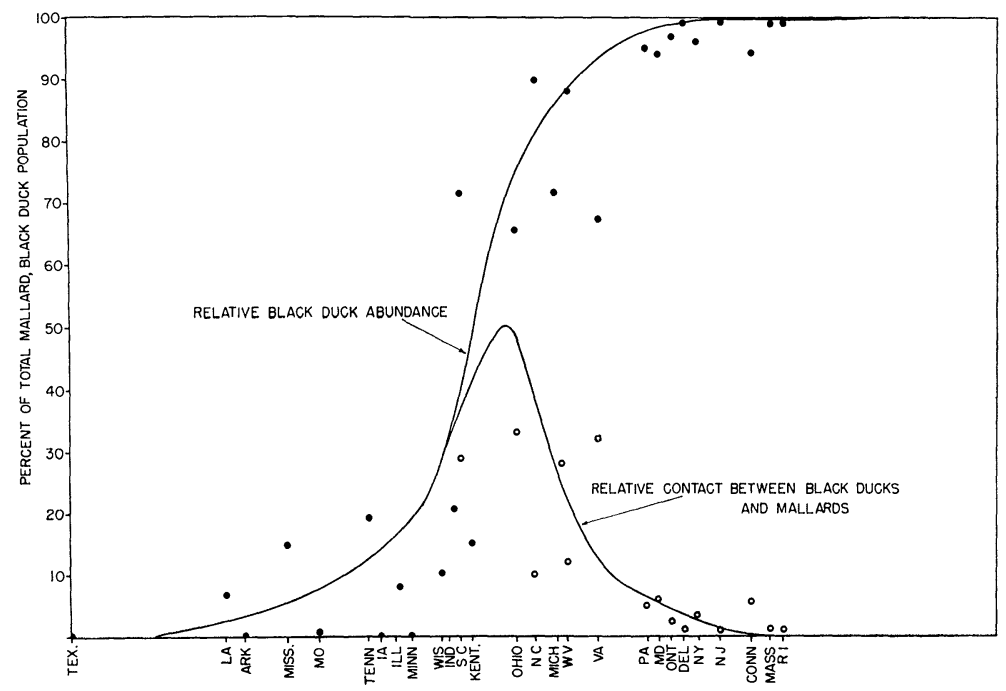

FIG. 1.-Black Duck percentages, various states and provinces, 1900-1939. Where Black Ducks exceed 50\% of the total Mallard, Black Duck population the Mallard percentages are also shown (open circles). See text for basis of abscissa. 
ever, by drawing a straight line on an equal-area map from the geographic center of Texas to the New Brunswick-Nova Scotia border, one achieves a transect that traverses most of the primary wintering states of both Mallards and Black Ducks and which passes from a zone of nearly "pure" Mallards to equally "pure" Black Ducks. Perpendiculars dropped from this transect to the approximate center of each of the states or provinces concerned provide a basis for an abscissa on which to plot geographic ratios. The validity of the placement of these ratios undoubtedly varies directly with the distance of each state or province from the transect line; thus, the data for those states farthest north (North Dakota) and south (Florida, Georgia) are excluded from the resulting diagrams (Figs. 1, 2). Furthermore, several states and provinces represented in the summary for the period 1960-1964 were not sampled in the earlier period, but a reasonable sampling for both periods is available over the entire zone of sympatry.

A sigmoid curve has been visually drawn in as representing average frequency changes from west to east but has not been statistically fitted to the actual points. Because some of the points are based on larger sample sizes or represent states or provinces closer to the transect than other, the points probably should be given differing weighted values if such fitting attempts were made. In addition, where Black Duck ratios exceed 50\%, the corresponding Mallard ratios are plotted (open circles), to provide an estimate of actual sympatry, since the percentage frequency of the rarer form may be regarded as an estimate of the degree of sympatric contact. A bell-

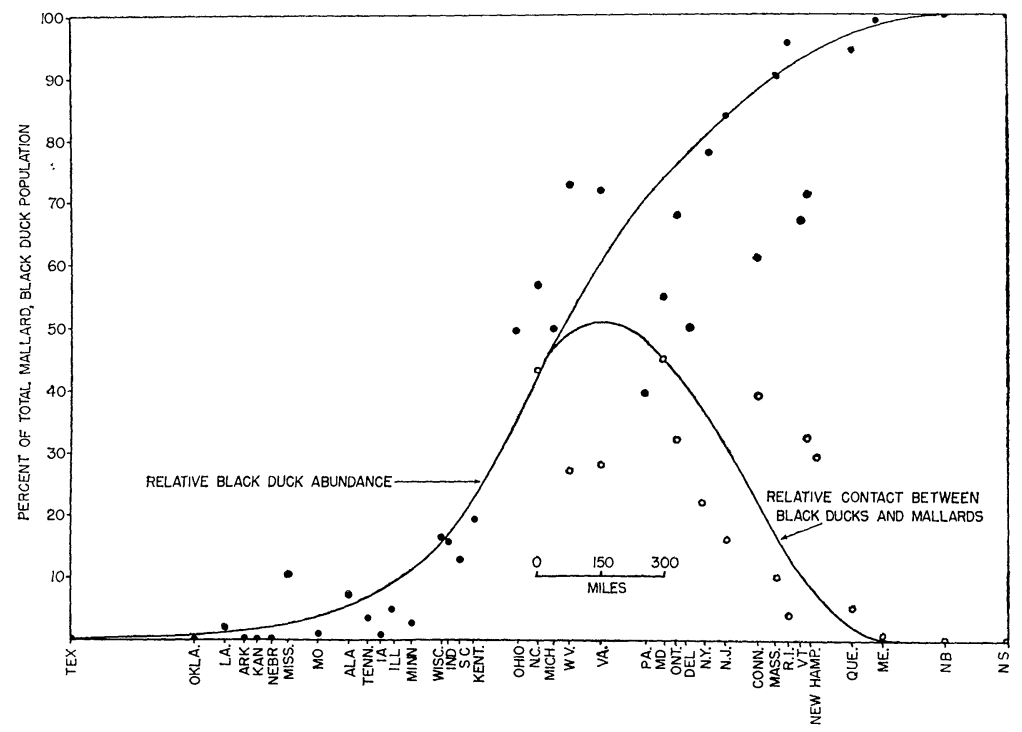

Fig. 2.-Black Duck percentages, various states and provinces, 1960-1965. Symbols and abscissa as in Fig. 1. 
shaped curve based on these percentages of the rarer form may be drawn as a result, which likewise has been visually fitted to the available points.

A comparison of the resulting curves for the two time periods shows several points of interest. Clearly, not only has the major zone of sympatry between the two forms moved approximately 300 miles to the east in the last half century, but also the total area of significant sympatry has greatly widened, resulting in a flattening of the sigmoid curve and a larger number of states in which the present ratios approach a 50:50 ratio (or maximum contact). The areas subtended by the bell-shaped curves might be regarded as rough estimates of the probabilities of mixed pairing, which are mathematically (if not biologically) greatest when the two populations are equally abundant in a locality. The area subtended in Fig. 2 is approximately 1.4 times larger than that in Fig. 1, suggesting that opportunities for hybridization have markedly increased in the past half century. By extrapolating this trend into the past, together with the rate of geographic change of maximum contact, it may be estimated that in the mid-1800's the zone of primary contact between the two forms was approximately the longitude of the Mississippi River. However, Mallards did reach the East Coast in small numbers at least as early

TABLE 2.-Summary of flyway ratios of Black Ducks, Mallards and Hybrids, early 1960's

\begin{tabular}{|c|c|c|c|}
\hline Flyway & $\begin{array}{c}\text { Total Black Ducks } \\
(\%)\end{array}$ & $\begin{array}{c}\text { Total Mallards } \\
(\%)\end{array}$ & $\begin{array}{c}\text { Total Hybrids }{ }^{1} \\
(\%)\end{array}$ \\
\hline \multicolumn{4}{|l|}{ Atlantic } \\
\hline $\begin{array}{l}\text { Audubon Counts } \\
(1960-1964)\end{array}$ & $637,998(67.10)$ & $312,634(32.90)$ & \\
\hline $\begin{array}{l}\text { Wing Survey² } \\
\quad(1960-1964)\end{array}$ & $670,091(63.74)$ & $381,179(36.26)$ & $19,013(1.81)$ \\
\hline \multicolumn{4}{|l|}{ Mississippi } \\
\hline Audubon Counts & $124,977(8.50)$ & $1,344,224(91.50)$ & 040 \\
\hline $\begin{array}{l}\text { Wing Survey² } \\
\quad(1960-1964)\end{array}$ & $281,381(8.02)$ & $3,228,100(91.98)$ & $14,748(0.42)$ \\
\hline \multicolumn{4}{|l|}{ Central } \\
\hline $\begin{array}{l}\text { Audubon Counts } 3 \\
(1960-1964)\end{array}$ & $94(0.001)$ & $900,323(99.999)$ & \\
\hline $\begin{array}{l}\text { Wing Survey } 2 \\
\text { '(1961-1964) }\end{array}$ & $1,373(0.11)$ & $1,195,631(99.89)$ & $391(0.03)^{4}$ \\
\hline \multicolumn{4}{|l|}{ Pacific } \\
\hline 1961-1963) & & & \\
\hline
\end{tabular}

${ }_{1}$ Not included when calculating Mallard and Black Duck percentages.

2 Based on weighted estimates for each state; summed totals of all years.

3 Excluding Montana, Wyoming, Colorado and New Mexico.

4 Possibly includes a few New Mexican Ducks. 
as that time, and a hybrid was sold in the Washington, D.C., market in 1871 (Baird, Brewer and Ridgway, 1884).

A more generalized picture of sympatry and hybridization may be obtained if the data are grouped into geographic areas made up of the multi-state administrative units called "flyways" by the Bureau of Sport Fisheries and Wildlife. In this case, Audubon counts have been summarized only for the Atlantic, Mississippi, and part of the Central flyway (Table 2), whereas comprehensive figures for all four flyways are available for essentially the same period through the use of the Duck Wing Collection Survey data. Extrapolated figures, weighted on the basis of sampling variations, provided the basis for these latter totals. Through these data the theoretically vulnerable position of the Black Duck's gene pool may be readily seen, as well as the general clinal variation in the frequency of these two forms from west to east. It was earlier estimated that the gene pool of the Black Duck was approximately $17 \%$ that of the Mallard in the eastern United States (Atlantic and Mississippi flyways) during the 1950's (Johnsgard, 1961a). If the relatively "pure" Mallard populations of the Central and Pacific flyways are taken into account, the present relative gene pool estimate of the Black Duck is diminished to about $3 \%$ of the Mallard's, on the basis of the Duck Wing Collection Survey data.

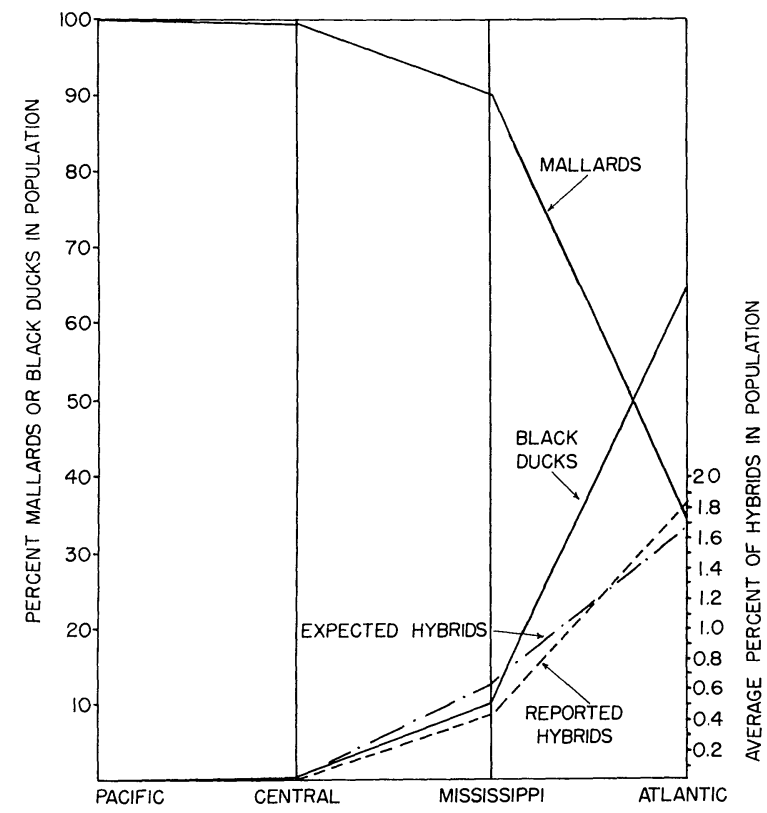

Fig. 3.-Relative abundance of Mallards, Black Ducks and hybrids in each flyway, based on Duck Wing Collection Survey data, 1960-1964. "Expected Hybrids" represents calculated curve resulting from random mating at rate suggested by reported hybrid data. 
More significantly, the numbers of hybrids reported through this survey show an interesting correlation with flyway ratios of the two forms. This correlation is best illustrated in Fig. 3, which represents a graphic summary of the Duck Wing Collection data in Table 2, plus an estimated expected hybrid incidence. This calculated expectation is based on the assumption of a small frequency of nonselective mating in direct proportion to the mathematical probability of contact between the two forms as determined by their relative abundance. The actual observed hybrid incidence closely follows the calculated incidence, thus supporting the hypothesis that nonselective mating is as likely to occur in areas of major sympatry as in peripheral zones of contact.

The calculation of expected hybrid incidence in this graph and in the graph which follows is based not only on the assumption of a small incidence of nonselective mating but also on the hypothesis that the difference between the Mallard and Black Duck plumages are controlled by, at most, a few pairs of incompletely dominant alleles. This is perhaps an oversimplification of the actual situation (Johnsgard, 1961a), but the model allows for a ready calculation of expected heterozygote (hybrid) phenotypes for any combination of pure parental frequencies. With a minimal difference of one pair of incompletely dominant alleles, a maximum of $50 \%$ heterozygosity would be expected in areas where the two forms are equally abundant; varying smaller percentages would occur where one form is distinctly rarer. according to the Hardy-Weinberg law. With increasing numbers of allele-pair differences between the two forms, the expected frequency of "hybrids" (all genotypes other than parentals) rapidly approaches $100 \%$ (Table 3). Where the two parental forms are present in unequal ratios the frequency of expected hybrid individuals is variably less, but also rapidly increases as differences in the number of pairs of alleles increase. Thus, even with a parental gene frequency of $.90: 10$, as at the edges of sympatric ranges, it might be expected that random mating among genotypes differing for any character by four incompletely dominant allelic pairs would result in less than $50 \%$ of individuals genotypically and phenotypically like either parental form for that character (Table 3). Because the expression of the male plumage differences between Mallards and Black Ducks is regulated

TABLE 3.-Expected frequencies of "hybrids" (nonparental genotypes) in mixed populations with random matings, with various frequencies of parental genes, and differing numbers of incompletely dominant alleles between populations

\begin{tabular}{lllll}
\hline \hline $\begin{array}{c}\text { Relative gene frequencies } \\
\text { of sympatric populations }\end{array}$ & \multicolumn{5}{c}{$\begin{array}{c}\text { Number of gene pair differences } \\
\text { between populations }\end{array}$} \\
\hline $50: 50(1: 1)$ & 1 & 2 & 3 & 4 \\
$60: 40(1.5: 1)$ & $48 \%$ & $87.5 \%$ & $96.88 \%$ & $99.22 \%$ \\
$70: 30(2.33: 1)$ & 42 & 74.48 & 94.92 & 98.25 \\
$80.20(4: 1)$ & 32 & 58.88 & 88.16 & 93.40 \\
$90.10(9: 1)$ & 18 & 34.38 & 56.78 & 83.22 \\
\hline
\end{tabular}


by perhaps as few as two pairs of incompletely dominant alleles (Johnsgard 1961a), less than $15 \%$ of the population in the zone of maximum sympatry should consist of phenotypically pure Mallards or Black Ducks, judging from their plumages. However, obvious hybrid Mallard x Black Ducks rarely exceed more than $2 \%$ of the combined population (Table 1), indicating that assortative mating is operating effectively.

To test further the apparent correlation between hybrid incidence and degree of sympatric contact, the hybrid frequencies reported in Table 1 have been plotted (Fig. 4) against the frequency of the rarer form as calculated by the Wing Collection Survey data (omitting Georgia and Florida, where there seems reason to doubt the validity of the data on the basis of sample size) for the states in the area of major sympatry. It may be seen that the resultant plotting of these points closely follows a calculated curve based on a small frequency of cross-mating in direct proportion to mathematical probability. That is, the curve represents $1 / 25$ th the expected maximum incidence of heterozygotes resulting from mating between two genotypes differing

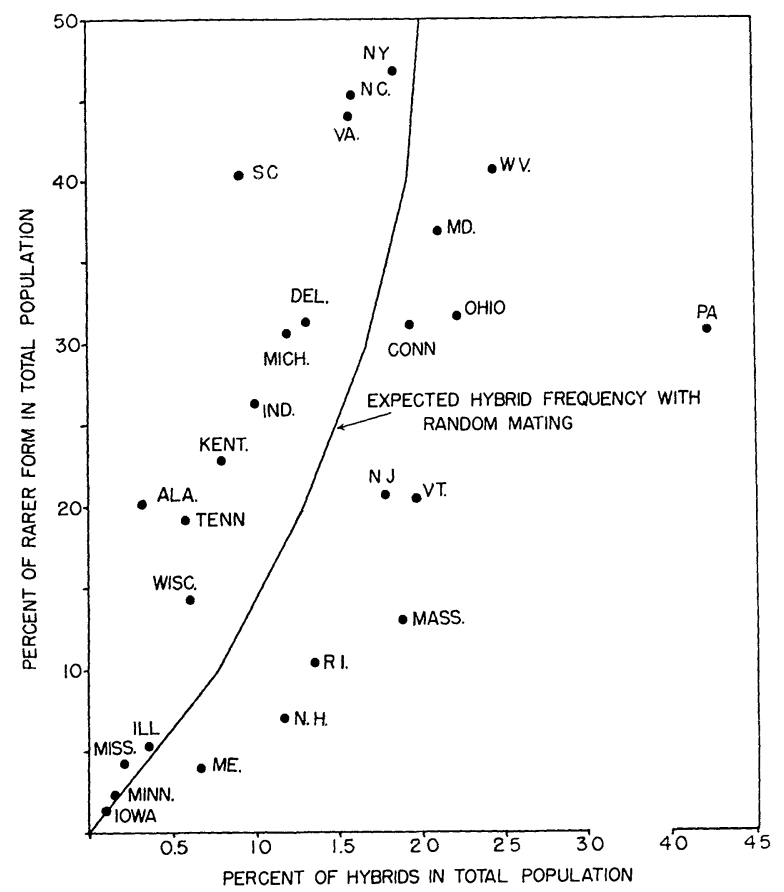

FIG. 4.--Correlation between reported hybrid incidence and frequency of rarer form in combined Mallard, Black Duck population, determined from 1960-1964 Duck Wing Collection Survey data. Curve represents 4\% of expected heterozygotes with difference of one allelic pair (see Table 3 ). 
by only a single pair of alleles, thus ignoring opportunities for mating with hybrids. With the exception of the unusually high hybrid incidence reported for Pennsylvania (where game farm birds have been released in large numbers) the resulting fit is very good. This supports the contention that isolating mechanisms are no better developed in the primary areas of sympatry than in areas of minor contact, an expected circumstance if reinforcement of isolating mechanisms were occurring. Thus, it must be concluded that equivalent degrees of intrinsic isolation occur throughout the zone of sympatry, probably through assortative mating on the basis of male plumage differences, and are over $95 \%$ effective. This degree of preferential mating on the basis of plumage is not surprising, inasmuch as Lill and WoodGush (1965) demonstrated a marked degree of plumage-based assortative mating among breeds of domestic fowl (Gallus gallus). Since the states showing hybrid incidences higher than the calculated curve include some states where Mallards predominate (Ohio, Pennsylvania), as well as some where Black Ducks are more common (Maryland, Connecticut), "mistakes" are evidently made by females of either form with equal likelihood.

It is of interest to compare these hybrid rates with others found in similar hybrid situations. Sibley and Short (1964) report that the incidence of heterozygous phenotypes approaches the theoretical maximum of $100 \%$ in the hybrid zone between the Baltimore Oriole (Icterus g. galbula) and the Bullock's Oriole (I. g. bullocki) in the Great Plains, and a similar situation exists with regard to the Yellowshafted and Red-shafted Flickers (Colaptes a. auratus and C. a. cafer) (Short, 1965) in the same general area. In most other reported cases, however, the incidence of hybridization is much lower, even in the area of primary contact. When figures become available for situations in which reinforcement is suspected it will be of interest to plot hybrid incidence against frequencies of parental forms to see if the expected situation, the reverse of that presented here (thus, hybrids rarest where parentals are equally abundant and most common where one form is rare), actually materializes.

Acknowledgments.-Stimulus for writing this paper came largely from reading Administrative Report No. 55 of the Migratory Bird Populations Station, Laurel, Maryland, in which Mallard x Black Duck hybrids were listed in the flyway analysis of the 1962 and 1963 U. S. waterfowl hunter kill. Mr. Glen Smart of that station very kindly extracted the individual state figures on which these estimates, as well as those of 1961 and 1964, were based. I greatly appreciate the permission to quote these figures given to me by the Director of the Bureau of Sport Fisheries and Wildlife. This study was partly financed by a National Science Foundation Grant (GB 1030).

\section{REFERENGES}

Baird, S. F., T. M. Brewer and R. Ridgway. 1884. The Water Birds of North America. Vol. 1. Little, Brown and Co., Boston. 537 p.

Johnsgard, P. A. 1960. A quantitative study of sexual behavior of Mallards and Black Ducks. Wilson Bull., 72:133-155. 
-- 1961a. Evolutionary relationships among the North American mallards. Auk, 87:3-43.

1961b. Wintering distribution changes in Mallards and Black Ducks. Amer. Midl. Natur., 66:477-484.

Lill, A. And G. G. M. Wood-Gush. 1965. Potential ethological isolating mechanisms and assortative mating in the domestic fowl. Behaviour, $25: 16-44$.

Phillips, J. C. 1915. Experimental studies of hybridization among ducks and pheasants. J. Exp. Zool., 18:69-144.

1921. A further report on species crosses in birds. Genetics, 6:366-383.

Short, L. L., JR. 1965. Hybridization in the flickers (Colaptes) of North America. Bull. Amer. Mus. Natur. Hist., 129:307-428.

Sibley, C. G. 1961. Hybridization and isolating mechanisms, p. 69-98. In Vertebrate Speciation, edited by W. F. Blair, Univ. of Texas Press, Austin.

- ANd L. L. Short, JR. 1964. Hybridization in the orioles of the Great Plains. Condor, 66: 130-150.

WiNG, L. 1943. Relative distribution of Mallard and Black Duck in winter. Auk, 60:438-439.

Submitted 7 Deaember 1965

Agcepted 16 Degember 1965 